\title{
Renal vein thrombosis complicating primary hyperparathyroidism
}

\author{
LESLEY A. SMALlMAN \\ M.B., Ch.B. (Hons) \\ Department of Pathology, The General Hospital, Birmingham B4 $6 \mathrm{NH}^{*}$
}

\begin{abstract}
Summary
The clinical and pathological findings in a fatal case of primary hyperparathyroidism presenting with a serum calcium of $6.18 \mathrm{mmol} / \mathrm{litre}$ and associated with renal vein thrombosis are described. Profound dehydration is thought to be the mechanism involved.
\end{abstract}

\section{Case report}

A 60-year-old housewife was admitted to hospital, with a 2-month history of malaise and muscle weakness. Closer questioning revealed that she had been anorectic with nausea, vomiting, constipation, epigastric discomfort and weight-loss during this period.

On examination, she was grossly dehydrated with a sallow, uraemic complexion. She was restless and at times confused and disorientated, but there were no localizing neurological signs.

Investigations showed serum calcium $6.18 \mathrm{mmol} /$ litre (corrected), phosphate $1.35 \mathrm{mmol} /$ litre, sodium $137 \mathrm{mmol} /$ litre, potassium $2.4 \mathrm{mmol} /$ litre, urea 25.5 mmol/litre, alkaline phosphatase $127.8 \mathrm{u}$./litre, blood pressure $130 / 90 \mathrm{~mm} \mathrm{Hg}$, heart rate $88 / \mathrm{min}$. The erythrocyte sedimentation rate was raised at 41 $\mathrm{mm} / \mathrm{hr}$. A chest X-ray was normal and an electrocardiogram showed ST depression. With no evidence of overt malignancy, hyperparathyroidism was thought to be a distinct possibility and attempts were made to control the hypercalcaemia. Large amounts of intravenous saline were given, followed by intravenous phosphate and later a combination of calcitonin and hydrocortisone. The following day her serum calcium was $8.15 \mathrm{mmol} /$ litre later falling to $4.65 \mathrm{mmol} /$ litre. Despite these measures, she had a cardiac arrest that day and resuscitation was unsuccessful. Subsequently, the serum parathyroid hormone level was reported to be grossly elevated at $17.5 \mathrm{ng} / \mathrm{ml}$ (normal under $0.2 \mathrm{ng} / \mathrm{ml}$ ).

At post-mortem the kidneys together weighed 130 g. Recent dark thrombi were distending the

\footnotetext{
* Present address: Dept. of Pathology, The Medical School, irmingham B15 2TJ.
}

interlobar and arcuate veins and both main renal veins were occluded to just short of the inferior vena cava. The left ureteric vein was also thrombosed. Near to the right lobe of the thyroid gland, there were two nodules $4 \times 1 \times 0.5 \mathrm{~cm}$ and $2 \times 1 \times 0.5 \mathrm{~cm}$, together weighing $36 \mathrm{~g}$, which were thought to be parathyroid adenomas. The maximum dimension of the other two parathyroid glands was 0.1 and $0.2 \mathrm{~cm}$. $X$-rays of the hands, shoulder and knee joints showed the classical changes of hyperparathyroidism with subperiosteal erosions, but there were no cysts or fractures. It was felt that the cause of death was severe hypercalcaemia as a consequence of primary hyperparathyroidism.

Histology confirmed that these nodules were parathyroid adenomas, predominantly of the oxyphil cell type. The other two parathyroid glands were normal. Sections of bone showed changes of osteitis fibrosa. There was metastatic calcification in the heart and stomach and, although there were no stones in the urinary tract, calcium deposition in and around the tubules of the kidney had resulted in fibrosis and tubular atrophy. Special stains of the kidney showed no evidence of glomerulonephritis.

\section{Discussion}

Parathyroid adenoma is the cause of most cases of hyperparathyroidism, being responsible for about $80 \%$ of cases of primary hyperparathyroidism (Roth, 1962). Usually only one tumour is present. Two adenomas were found in only $1 \%$ of a series of 813 cases reviewed in 1969 (Hoehn, Beahrs and Woolner, 1969). Histologically the chief cell dominates in well over half the cases; about 3\% of tumours consist largely of oxyphil cells (Woolner, Keating and Black, 1952). This case is therefore unusual in that two large oxyphil adenomas were found.

There has been little documentation of renal vein thrombosis occurring in hyperparathyroidism. The first case was reported by Smith and Cooke in 1940. Since then, it is believed that only three other cases have been reported in the English literature (Horowitz and Berenbaum, 1958; Pringle and Smith, 1964) 
and in all of these solitary chief cell parathyroid adenomas were found.

It is well known that renal vein thrombosis occurs in infants with epidemic diarrhoea and the mechanism is thought to be dehydration (Karafin and Stearns, 1964). Renal vein thrombosis has been reported in neonates, born to diabetic mothers, who have glycosuria and a solute diuresis with secondary dehydration (Avery, Oppenheimer and Gordon, 1957). The renal vein thrombosis in this case is probably due to a similar mechanism. Severe hypercalcaemia leads to gross dehydration; the resulting haemoconcentration causes a decrease in renal blood flow with sludging of the venous circulation in the kidneys producing thrombosis in the main renal veins and smaller vessels of the parenchyma. The rarity of this condition in hyperparathyroidism is presumably due to the rarity of such severe degrees of hypercalcaemia.

\section{Acknowledgments}

I would like to thank Dr B. L. Pentecost for permission to publish this case under his care and Dr D. A. Heath and Dr H. Thompson for their encouragement and advice. I am also grateful to Miss A. Wright for typing the manuscript.

\section{References}

AVERy, M.E., OPPENHEIMER, E.H. \& GoRdON, H.H. (1957) Renal vein thrombosis in new-born infants of diabetic mothers. New $\overline{\bar{C}}$ England Journal of Medicine, 256, 1134.

HoEHN, J. G., BEAHRS, C.H. \& WoOLNER, L.B. (1969) Unusual $\overparen{\triangleright}$ surgical lesions of the parathyroid glands. American Journal of
Surgery, 118, 770 .

Horowitz, W. \& Berenbaum, A.A. (1958) Primary hyperparathy- $\overrightarrow{0}$ roidism due to parathyroid adenoma: an antemortem diagnosis with termination in possible acute parathyroid intoxication. $\overrightarrow{\vec{\omega}}$ Annals of Internal Medicine, 49, 181.

KARAFIN, L. \& STEARNS, T.M. (1964) Renal vein thrombosis in children. Journal of Urology, 92, 91.

PRINGLE, A. \& SMITH, E.K.N. (1964) Renal vein thrombosis in acute 3 . hyperparathyroidism. British Medical Journal, 2, 675.

RoTH, S.I. (1962) Pathology of the parathyroids in hyperparathyroidism. Archives of Pathology, 73, 495.

SMITH, F.B. \& COOKE, R.T. (1940) Acute fatal hyperparathyroidism. Lancet, ii, 650 .

WoOlNeR, L.B., Keating, F.R. \& BLACK, B.M. (1952) Tumours $\stackrel{\oplus}{\rightarrow}$ and hyperplasia of the parathyroid glands. Cancer, 5, 1069. 